\title{
Replacing safe havens with a safe system
}

\author{
by Jonathan M Winer
}

\begin{abstract}
At the recent Sixteenth International Symposium on Economic Crime, Jonathan Winer analysed the background to recent worldwide financial services collapses. The text of Mr Winer's presentation is reproduced here.
\end{abstract}

$\mathrm{I}$ recent weeks, we have had a major crash in the middle of the financial services electronic highway, and hundreds of millions of people are already feeling the shock from the impact, even if they were nowhere near the site of the impact in Moscow.

The current Russian crisis simultaneously poses threats to the world's capital markets, Eurasian political stability and democracy in the Newly Independent States, in addition to the viability of the market reforms the International Monetary Fund has been seeking to put in place all over the earth. It provides a perfect case history of the relevance of the theme of this conference, The Prevention and Control of Economic Crime Against Governments, to both national and international security.

\section{CAUSES OF THE RUSSIAN CRISIS}

There have been many analyses of the causes of the recent Russia crisis. Its relationship to the problem of economic crime provides a window into vulnerabilities in our system of financial supervision, regulation, and enforcement that are literally global.

For years, analysts have suggested that the viability of Russian reform was threatened by Russia's lack of transparency, inadequate regulation, inadequate law enforcement, corruption and organized crime. They noted that financial crime threatened the integrity of Russia's financial systems and simultaneously fuelled many other types of criminal activity, discouraged foreign investment, facilitated capital flight, and robbed Russia of the resources it needed to move forward with privatization and modernization.

But despite the profound flaws of its political, juridical and financial systems, Russia is not itself the problem. Russia is not unique; it is not even that unusual. The recent global raging bear market is merely the freshest reminder that global capital flows and global technologies have out-paced the ability of governments to regulate or to enforce the rules necessary for efficient markets. Instead, in country after country, we see financial discontinuities, anomalies, inadequate regulation, and fraud, leaving the world subject instead to sudden, wild gyrations in financial markets.

Mexico has had many of the same problems in its political and financial systems as Russia has had, with as much corruption in evidence as transparency and regulatory integrity has been missing. Mexico, like Russia, was a miracle of the marketplace, until in early 1995 , the miracle proved mirage and transparency, poor auditing, weak regulatory controls, and the shared participation of its banks and its local form of organized crime, the Yakuza, in real estate speculation. For much of the 1990 s, Japan has been in a slow free-fall, which continues to this day. Last year, what was then called the Asian Financial Flu spread through Malaysia, Indonesia, South Korea, and Thailand. Each of these financial sector collapses, like the most recent Russian problem, took place in environments that featured poor regulation, weak law enforcement, little financial transparency, a fair degree of official corruption, and no laws against laundering money.

Lesser known financial collapses have had similar features. For example, the collapse in 1995 of Latvia's largest commercial bank occurred because the bank had been controlled by a criminal group, that used the bank to make bad loans to its front companies and defrauded the bank's accounts of as much as $\$ 40 \mathrm{~m}$. That collapse provoked a major financial crisis in Latvia, contributed to a change in the government, and forced Latvia to seek short-term assistance from the International Monetary Fund (see President's International Crime Control Strategy, The White House, May 1998, p. 18). Similarly, a series of pyramid or 'Ponzi' schemes in Albania last year stripped the country of more than $\$ 250 \mathrm{~m}$ in capital, causing the government to collapse, as hundreds of thousands of impoverished refugees fled to Italy.

The flaws in our current system of governance in the area of international financial service activities should not surprise us. As technology globalized financial markets beyond national borders, governments, regulators and law enforcement agencies stayed at home, their responsibilities most often limited to overseeing domestic activities of entities and markets. While anyone with a computer, modem and bank account had the ability to move funds throughout every jurisdiction in the world, no government regulator or law enforcement agency was simultaneously granted the ability to trace funds through any jurisdiction but its own.

We created a financial services electronic highway without enforceable speed limits and without highway patrols. The recent Russian crack-up has thrown debris all over that highway, causing all kinds of collateral damage to everyone else relying on the same infrastructure to move around, before the repair crews had completed their work on Indonesia, Malaysia, Thailand and Japan. As we clean up from this latest major accident, we need to think about what kind of rules we can put in place now to reduce the risk of additional accidents happening while we are still undertaking repairs. We need also to be working on longer- 
term changes to impose enough regulation and enforcement within the global financial services system to ensure a reasonable level of protection for all its billions of individual and corporate users, regardless of where they are located.

\section{SMOKE SIGNALS}

In analysing what has gone wrong, it may be useful to look at what was said about the problem before a crack-up actually occurred, in a test case like Russia. Switching metaphors, in reviewing the diagnosis of the patient before the heart attack, it may be easier to recognize what kind of measures could have been undertaken as preventive medicine in the comfort of home, rather than as emergency surgery in the field. In the case of Russia, the diagnosis was made years ago and prescriptions provided, but then largely ignored by doctor and patient alike. In March 1996, in its annual report on drug trafficking and money-laundering, the US State Department diagnosed the problem in Russia as follows:

'Criminal and fraudulent activities in the Russian banking sector and the prevention of such activities have serious potential implications for the safety and soundness of the banking system and consumer confidence in the commercial banks as an integral institutional component of a market economy' (US Department of State, International Narcotics Control Strategy Report, March 1996, p. 581)

A year later, State warned that:

'continued growth of economic crimes in the financial sector, inefficient tax and government enforcement mechanisms, and the prevalence of capital flight suggest significant money-laundering activities that warrants immediate remedial action by Russian authorities. The shadow economy is a breeding ground for corruption, money-laundering, and a source for further criminality, criminal, and organized crime' (International Narcotics Control Report, March 1998, p. 579).

The report emphasized the considerable weight that off-shore business activity by Russians was imposing on Russia's financial services system, noting that billions of dollars in credit were being extended by Russian entities as overseas loans which appeared to be unregistered capital flight.

In March 1998, State again warned that 'the volume of Russian offshore business activity is high', specifying that this activity was taking place in such offshore zones as Ireland, the UK dependencies in Europe, offshore locations in the Caribbean and the Pacific, creating a serious enforcement problem that made tracing the funds increasingly impossible (International Narcotics Strategy Reports, March 1998, p. 645-648.

The State Department's reports on Russia emphasized inadequate regulation and enforcement at home, capital flight, and the use of offshore financial havens overseas. As a result, Russian law enforcement could not investigate and prosecute financial crime and money-laundering with an international dimension. In making these observations, was the State Department focusing on a distinctly Russian problem, or one of more universal applicability?

Information contributing to answering that question is answerable through reviewing the banking registries of the islands of the South Pacific, one of the new centers of the world's off-shore industry and, not coincidentally, home to a large percentage of Russia's offshore banks.

\section{BANKERS OF THE SOUTH PACIFIC}

The post-colonial South Pacific is home to a number of young countries characterized by tiny populations, limited governmental resources, and economic monocultures. These countries typically have no industry and few comparative advantages apart from the natural resource of bird guano phosphates and tourism. Yet over the last few years, these atolls have sprouted vigorous financial services industries, whose sole purpose would seem to be financial crime.

\section{Cook Islands}

Recently, the Department of State reviewed a group of offshore entities based in the Cook Islands, a group of 15 coral islands in the heart of the South Pacific, spread over an area the size of India, with a population of just 18,000 souls and 3,000 separate, registered, anonymous off-shore trusts. The review revealed connections between this village-sized 'nation-state', organized crime, Russia, and the some of the most notorious financial players in the Asia Pacific region.

The first names among the Cook Islands' bankers to leap out to an American reviewer were those belonging to a well-known Italian family under investigation by Italian authorities for numerous company offenses and bankruptcies, frauds, assaults, conspiracies, receiving, contraband, currency and banking offences.

Also on the list of Cook Island bankers were certain Brazilian politicians under investigation in Brazil for narcotics moneylaundering. The list included too the names of six Paraguayans, several Russian speakers operating out of Cyprus and a number of Indonesian banks, including the now notorious Lippo Group, allegedly involved with money-laundering and illegal campaign contributions in connection with the last round of American presidential elections.

\section{Naura}

Nauru, another nation of 18,000 people in the middle of the South Pacific, whose economy has largely been built on the export of bird guano, today has some 288 licensed offshore banks. Among its offshore bankers are a Latvian gentleman under investigation in Riga for allegedly stealing $\$ 20 \mathrm{~m}$, a number of Ukrainians and Russians, the notorious Dragon Bank, alleged to have engaged in massive financial crime and money-laundering, before its license was revoked in 1997, a Malaysian investigated recently for being a conduit for laundering drug profits from the Cali cocaine cartel in Colombia, and an Australian in the business of transiting large sums of Iranian currency.

\section{Samoa}

In Samoa, the newly created offshore industry features only 15 offshore banks. This small sector, however, already includes among its bankers a Russian who travels on Honduran and Russian passports, and who has some 300 offshore companies also registered in Samoa. Its other bankers include a Greek and a Russian arrested in Malta for operating an unlicensed bank, misappropriation of funds and forgery, a Swiss banker known unfavorably to Swiss authorities, a Ukrainian-Israeli, a Lebanese based in Beirut, another gentleman with a Swiss criminal record, some people whose addresses in the US turned out to 
be false, and a Russian individual who is currently in the custody of European law enforcement.

As this summary suggests, the offshore bankers of the South Pacific include a fair number of criminals, operating in these tiny jurisdictions precisely because they are tiny, under-regulated, and protected from international law enforcement. Years ago, the location of these islands would have made them extremely undesirable sites for international finance, because the lack of infrastructure would have made financial dealings through them slow, inefficient, and unreliable. Today, every one of these jurisdictions is available for use to anyone with an Internet address, with transactions that go through their institutions treated no differently by the world's financial services industry than transactions that go through the major banks of Paris, Tokyo, London, Hamburg, and New York. These jurisdictions are able to attract the business of money-launderers and other criminals because they have the technical advantages of the major financial centers - access in real time to the world's financial markets and investments, without the disadvantages - oversight, regulation, law enforcement, transparency

The legal regimes in these mini-states that are useful for criminals are indistinguishable from those useful for terrorists, for drug-traffickers, for fraudsters, for tax evasion and for capital flight. The environment for protecting capital flight and for tax evasion is indistinguishable from the environment suited for serious financial crime. Financial crime of whatever nature breeds in the same kind of house, breathes the same kind of air, procreates and flourishes under the same kinds of legal and bureaucratic frameworks.

The globalized economy has intensified this problem, by blurring to near obliteration the borders between domestic and foreign financial activity. What is really offshore in a globalized economy? What is really onshore? How can anyone tell the difference? If 'offshore' has no rules, why should anyone live by the rules 'onshore' when all it takes to go 'offshore' is a modem and a bank account? Under these circumstances, what rules should exist for 'offshore' financial institutions to ensure that they do not undermine the safety and soundness of institutions that are 'onshore'? If New York and Vanuatu have the same electronic access to financial markets, how might we develop rules that take into account the differences in the regulatory schemes that govern them? fact that it had a $\$ 5$ billion hole in its books that left it with no working capital. As regulators and law enforcement officials ultimately proved, BCCI did so by hiding the losses in subsidiaries in the Caymans and the Dutch Antilles. Ten years later, when Daiwa bank suffered massive losses in its commodities trading operations, it too turned to the offshore world to hide its losses, a scheme that was only discovered not by effective bank regulation, but because one of the insiders became an informant for prosecutors. The Venezuelan banking crisis of the mid-1990s went through the same process of seeing massive capital losses from insider lending being hidden through offshore operations in the nearby Antilles. Japan's crisis has had similar patterns: bad loans, fraud and an account manipulation overseas to keep the day of reckoning at bay.

The sudden institutional collapses of a BCCI, a Barings Investment Bank, or a Crédit Lyonnais, which hid losses of some $\$ 35$ billion 'offshore' in nearby Luxembourg, do not merely damage shareholders, suddenly wiping out capital. They do not merely devastate depositors and creditors and leave, in most cases, losses so large that governments and their taxpayers are required to bail out the victims. They have been warning signals, over the past decade, of the risks of an unregulated international financial services sector that continues to demonstrate its inability to police itself. They have been predictors of the kinds of instabilities that we have since seen affect entire countries and entire regions, and which have now impacted'the capital markets of the entire world.

The current financial crisis in Russia is thus best viewed as merely the latest wave in a cascade that requires systematic changes in how we all do business. The international financial markets move money through countries that have excellent record-keeping, regulatory, and auditing practices, and through countries that have essentially none, treating all the electronic digits as if they are the same, regardless of the route they take on the way to where they are reinvested. This breathtaking egalitarianism has, in a number of cases, masked underlying financial realities, so that money has appeared to exist when in fact the underlying capital was no longer available. The amazing global infrastructure for moving money has been tripped up because the infrastructure cannot see whether these electronic digits adequately represent reality in the world outside.

For us to continue to feel safety and reliability in the electronic on the internet

www.fas.org/irp/congress/1992_rpt/bcci/index.htm
A detailed account of BCCl's use of offshore havens to commit financial crime is contained in The BCCI Affair: A report to the Committee on Foreign Relations US Senate by Senators John Kerry and Hank Brown (December 1992); available on the above site.

The answers to these questions are of interest not only to the South Pacific, Caribbean and Mediterranean financial havens, but to every government and to every major financial services sector in the world.

\section{MOUNTING LOSSES}

These issues began to be raised in the mid-1980s, when the

\section{TAKING THE CURE}

In broad outline, the principles for action have largely already largely been identified and are contained in the FATF's 40 Recommendations, the CFATF's 19 Recommendations, the Organization of American States (OAS) Model Regulations, the European directive on money-laundering (Directive 91/308, OJ 1991 L166/77), and the Basle Principles. In some countries, these principles have yet to be legislated. In others, they are matters of law, but not of implementation. Some of the most 
important near-term actions include:

(1) Broadening money-laundering legislation beyond narcotics to the widest group of predicate criminal offenses.

(2) Eliminating systemic weaknesses, through ensuring that financial services firms maintain adequate records, know their customers, and report suspicious transactions.

(3) Engaging in adequate enforcement actions, such as revoking licenses of institutions that do not maintain adequate records or report suspicious transactions, or whose overseas activities reflect involvement in money-laundering or financial crime.

(4) Regulating exchange houses and remittance systems, such as the 'hundi', 'hawala', and 'Chop' systems in the Middle East, South and East Asia, as well as the 'cambios' of Latin America.

(4) Applying transparency, anti-money-laundering, and financial crime enforcement mechanisms to non-bank financial services sectors, including investment banks, insurance, commodities trading, derivatives, international business corporations, offshore banks, and assets held by foreign trusts.

(5) Completing the building of a web of intelligence and information sharing on financial crime, through the further development of FUIs that meet Egmont Group standards, and which are able to share information with one another through the Egmont Group secure website.

Beyond these standard elements for next steps, are some possible innovations that would exceed current international practice, to provide greater reach for law enforcement and less impunity for financial criminals. These steps include the following.

\section{Asserting universal jurisdiction over and access to records}

No nation can protect its citizens if they do business with someone whose activities, records, property, and person remain beyond the government's reach. The US has long asserted very broad jurisdiction over the documents it needs from financial services providers when it comes to criminal prosecutions, through a doctrine that is sometimes known as the 'Bank of Nova Scotia' doctrine, for the money-laundering case where it first arose. Mutual legal assistance treaties are a major new mechanism by which countries may co-operate with one another in retricving essential evidence of financial crimes. The UN Convention on Organized Crime, currently under negotiation in Vienna, will create a universal system for mutual legal assistance in cases involving serious organized financial crime. But countries can exercise self-help as well, making the right to do business in their country contingent on agreement to make records available to law enforcement in connection with investigations of serious crime. Such a provision, if universally adopted, would do much to protect shareholders, depositors, and creditors from having no remedy in the event of something going wrong. Simultaneously, the Group of Eight and the Council of Europe need to complete their work on the problem of 'high tech crime'. Currently, both groups are considering rules to ensure that Internet service providers and the financial services infrastructures retain records of traffic for a sufficient period so as to permit law enforcement and regulators to reconstruct financial transactions when something has gone wrong. In addition, they are seeking to construct universal principles for the assertion of jurisdiction, and mechanisms to trap and trace electronic transactions, in cases involving transnational crime. Adoption of such universal rules will be necessary to reduce the threat posed if some jurisdictions do not require records to be maintained, or do not permit records maintained in their jurisdiction to be accessed, in cases involving financial crime.

\section{Refusing to accept bank secrecy in cases involving financial crime}

Nations cannot protect their citizens from financial crime if financial criminals are able to shield their criminal conduct through the use of bank secrecy. Jurisdictions that do not permit law enforcement to gain access to financial records in cases involving allegations of criminal conduct turn themselves into safe havens for financial criminals. Just as the EU has sued its member, Austria, to stop its issuance of anonymous banking accounts, the Financial Action Task Force and other international bodies need to consider taking appropriate measures to sanction countries that have become safe havens for financial criminals. Such sanctions need not be anything that would impair the ability of financial markets to function normally. When the Seychelles developed a package of economic citizenship that purported to include protecting criminal proceeds from international law enforcement, the Financial Action Task Force asked all its members to treat transactions with the Seychelles as 'suspicious transactions', requiring immediate referral to law enforcement. Such an approach could develop into a two-tier system for international banking transactions: the top tier, including countries that meet the FATF recommendations, would have their transactions treated normally. Countries not permitting overseas regulators or law enforcement to have access to financial records would have their transactions subjected to additional regulatory controls. The most egregious would be subject to an automatic presumption that the transaction is suspicious, to be stored and analyzed by national FIUs. This type of two-tier system would reflect the actual risks to the global financial system inherent in having portions of that system act as black holes out of which information may not be recovered.

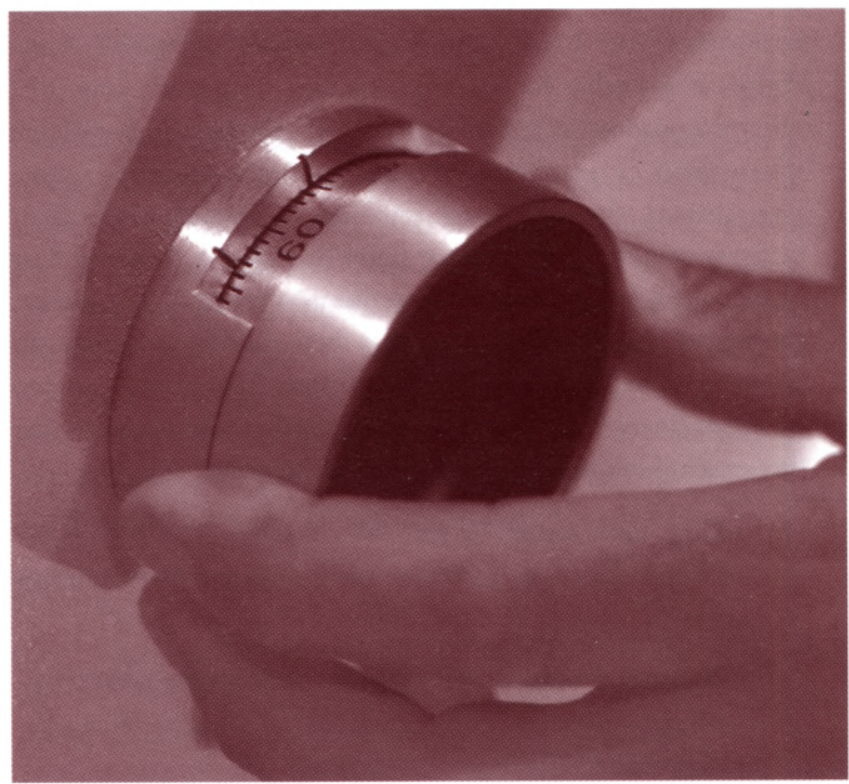




\section{Eliminating differential treatment of offshore transactions}

The offshore concept is based on a notion that what is necessary to regulate transactions involving the citizens of one's own country is not necessary in handling transactions involving the citizens of other nations. Its impact has been to encourage some financial institutions deliberately to structure themselves so that they are not regulated by anyone. Recently one such institution, Caymanx Bank, structured itself so that its operations in the Isle of Man were offshore to the Isle of Man, because it was a subsidiary of an institution in the Caymans. It was also offshore to the Caymans, because it was only doing business in the Isle of Man. As a result, its activities were effectively free of regulation, and its clients' records were advertised on the Internet as being free of oversight by the authorities of any jurisdiction. Whatever the economic justification for such differential treatment in the past, when national laws imposed tariffs on many forms of economic activity, treating as offshore anyone's transactions in any institution one licenses makes no sense. Such differential treatment is inappropriate now that everyone is using the same technological infrastructure, and when it is increasingly difficult to determine the actual national origin or citizenship of any individual or corporate user of this global system. We should be moving towards an international system where 'offshore' means the same as 'onshore', requiring the same regulations, the same access to records, the same law enforcement. Over time, jurisdictions that continue to offer under-regulated 'offshore' services will develop reputational problems that drive off legitimate businesses in any case. But in the meantime, to protect ourselves from the consequences of the abuses inherent in offshore financial services, firms based in offshore jurisdictions which are inadequately regulated should be subjected to additional due diligence by major clearinghouse banks.

\section{Eliminating the 'it's only tax evasion' loophole}

One of the great difficulties in developing information on a timely basis in financial crime cases is the problem of proving that money hidden in shell companies, international business corporations, or trusts, is the proceeds of criminal activity, rather than 'mere tax evasion.' In the US, some of the most important federal prosecutions of serious organized crime figures responsible for contract killings, drug-trafficking, and other extraordinarily serious crime, have only succeeded through the making of tax cases. In such domestic organized crime prosecutions, the inability of criminals to explain where their money came from and the clear frauds involved in their handling of the funds, made criminal prosecutions successful. By contrast, the generally accepted principle that there is nothing wrong with handling mere 'tax evasion' money offshore has created a swamp in which financial criminals breed. Nations could eliminate the 'tax evasion' loophole through three techniques:

(1) adding tax evasion to the list of predicate offenses for money-laundering in their own anti-money-laundering laws;

(2) including tax evasion among the grounds for the elimination of bank secrecy in the provision of documents to law enforcement; and
(3) amending mutual legal assistance agreements to include tax offenses.

If such an approach became generally accepted, nations that continued to make themselves available for tax evasion aimed at other countries might well find that the potential damage to their reputation from remaining outside this new system outweighed the potential income from continuing to offer these services.

\section{Co-operating in repatriation of assets and broadening civil remedies}

Too often, victims of financial crime find themselves unable to reach the assets of those who have victimized them. Governments need to look at mechanisms to permit early immobilization of assets of financial criminals and mutual assistance in ensuring that the immobilization is international, not merely domestic

Governments should consider assigning agents from several law enforcement agencies to work together in a task force approach against particular targets. They may also wish to consider providing for an adequate array of civil causes of action for victims of financial crime, against institutions who have facilitated the crime, as well as against the actual perpetrators. Governments may wish to determine where and when financial institutions doing business in their countries should be held at risk for losses to financial criminals occasioned through the use of their institutions. Failure to adopt and implement mechanisms to ensure the 'know your customer' principle, in a case where the 'customer' proved to be engaging in a pattern or practice of fraudulent activity, could lead to civil liability to victims. Such a finding of civil liability could in turn lead to enhanced compliance practices, on the part not only of the first financial services firm unfortunate enough to become the test case, but by becoming the basis of enhanced compliance throughout the industry.

\section{OUT OF REACH}

No nation can protect its citizens if they do business with someone whose activities, records, property and person remain beyond the government's reach.

\section{Linking future global financial assistance to strengthened supervision and enforcement}

The IMF, the US and Europe have provided billions to Russia without tying this assistance to enhanced rule of law, law enforcement and financial regulation. Future global economic assistance to any country or region needs to connect law enforcement and regulatory reform with economic reform. This need not involve conditionality, but instead concurrent initiatives such as agreement to strengthen the role of central banks in auditing and inspecting the banks they regulate and to further protect them from political influence. Such audits could help ensure that central banks enforce compliance with law, as well as with safety and soundness provisions consistent with international standards. Among the actions to be undertaken would be establishing public, transparent professional standards for such industries as accountants, auditors, engineers, property appraisers, insurance and financial service companies, and 
requirements for the issuance and regular renewal of business licenses and permits. The International Monetary Fund could play an especially helpful role here, by insisting upon such measures as core elements of its lending and programmatic support to countries in transition or in crisis.

\section{Legislating transparency in government and public disclosure for public officials}

Transparent government procurement and decision-making inhibits bribery and corruption, important factors in criminal exploitation of financial systems and institutions. The adoption of mechanisms to increase the integrity of governments and public officials in these areas are closely related to mechanisms that increase the integrity of the financial systems used by the public sector and private sectors alike. Efforts under way at the OECD and in Central Europe and Latin America, to combat corruption through the mechanisms of the Council of Europe and the OAS, could be supplemented by commitments by every nation to the principles of transparency in government. Such transparency might well make it easier for nations to take the other steps needed to combat financial crime, by attenuating the ability of would-be financial criminals to purchase the kind of legislative environment needed to facilitate their activities. During the next few months, the US will be undertaking new initiatives to promote anti-corruption standards in other parts of the world, perhaps through a global instrument that incorporates the work already undertaken at the OECD, OAS, and Council of Europe, incorporating a mutual assessment process.

\section{GETTING THERE}

Having a carefully developed recipe provides guidance to the cook, but the proof of the pudding is in the eating. The proposals articulated here represent the ingredients of a policy that will be fed to hungry policymakers in the coming months under the pressure of a series of external deadlines as inexorable as the progression of breakfast, lunch and dinner. It remains to be seen which of the courses the cooks have been sweating over back in the kitchen will prove most palatable when served up at table.

Let us begin with the mandate of the Birmingham Summit of the Eight of May 13-15, 1998. There the summit leaders of the eight industrialized nations warned 'there must be no safe havens either for criminals or for their money.' They committed the Eight to take vigorous action against the problem through a series of steps, including:

- The negotiation within the next two years of an effective UN convention against trans-national organized crime that will provide our law enforcement authorities with the additional tools they need.

- Implementing rapidly ten principles and a ten-point action plan agreed by our ministers on high tech crime, including the creation of a 24-hour-a-day team of experts in each country to assist one another in cases involving high tech crime, seven days a week, 365 days a year. To combat financial crime, including abuse of the Internet and other new technologies, the summit leaders called for close co-operation with industry to reach agreement on a legal framework for obtaining, presenting and preserving electronic data as evidence and agreements on sharing evidence of those crimes with international partners.

- Further attention to the problem of offshore financial centers.

- Establishing FIUs where we do not already have them to collect and analyze information on those engaged in moneylaundering and liaise with the equivalent agencies in partner countries.

- Agreement on principles and the need for adequate legislation to facilitate asset confiscation from convicted criminals, including ways to help each other trace, freeze and confiscate those assets and, where possible, in accordance with national legislation, share seized assets with other nations.

Many of the next steps will be in the hands of the private sector. To protect themselves, private firms will necessarily have to intensify due diligence, internal compliance, and risk assessment efforts. Without such steps, major institutions will find themselves recurrently forced to take major losses of the kind that some international banks experienced this past August in Russia. During the months to come, such efforts will prove important in reducing the risk of one's institution becoming liable to others victimized by lack of transparency or by financial crime. It is far harder to be held civilly liable in civil litigation when one has adopted and implemented all relevant best practices. If one has not done so, the potential risk to suit by plaintiffs' lawyers can be profound. By contrast, having adopted best practices, a firm is in the position to more or less define whether its competitors have put in sufficient controls themselves.

Through this mechanism, an entire industry's practices can transform themselves quickly. We saw this in the US during the 1980s. A few prosecutions of and civil suits against banks, their corporate officers, members of their boards of directors, and their outside auditors, asserting their liability for financial losses associated with the Savings and Loan Industry had an immediate prophylactic impact, intensifying their efforts to ensure they had practices in place to discourage fraud. The US has repeatedly found that criminal and civil action against private sector wrongdoers is a remarkably effective mechanism to transform industry wide standards of compliance. One obvious next candidate in the US for this mechanism, following the now notorious case of Carlos Salinas' use of Citibank in Mexico, would be the targeting of the private banking services offered by major international banks. On this, perhaps we will sec more soon.

As we undertake these steps and others, we will not become 'crash-proof', nor will we wipe out financial crime. We will have hardened our target to the attacks of the unscrupulous, made it harder for criminals and terrorists to get away with financial crimes when they occur, facilitated our ability to trace their assets and bring them to justice. If we are able to take the principles of 'hnow your customer' and transparency seriously, and make them universal principles that are universally implemented, we may even succeed in reducing the threat of instability to the worlds financial markets.

\section{Jonathan $M$ Winer}

Deputy Assistant Secretary of State, Narcotics \& Law Enforcement 